\title{
Herbage and Seed From Texan Native Perennial Herbaceous Legumes
}

\author{
James P. Muir, ${ }^{1}$ Judy Taylor, ${ }^{2}$ and Sindy M. Interrante ${ }^{3}$ \\ Authors are: ${ }^{1}$ Associate Professor, Forage Physiology, Texas Agricultural Experiment Station, 1229 North US Highway 281, \\ Stephenville, TX 76401; ${ }^{2}$ Stephenville High School Biology Teacher, 2650 W Overhill Dr, Stephenville TX 76401; \\ ${ }^{3}$ Graduate Student, Tarleton State University, Stephenville, TX 76401.
}

\begin{abstract}
Native seed mixes for rangeland seeding, prairie restoration, or cultivated pasture can benefit from a greater variety of forbs that more closely reflect the original vegetation of the southern Great Plains. Fifteen native, perennial herbaceous legumes were collected in central Texas and evaluated for herbage production, mineral content, and fiber concentration of established plants in research plots over 2 years. Downy milk-pea (Galactia volubilis [L.] Britton) was productive, regardless of rainfall, whereas prairie acacia (Acacia angustissima [Mill.] Kuntze var. hirta [Nutt.] B.L. Rob.) and Illinois bundle-flower (Desmanthus illinoensis [Michx.] MacMill. Ex. B.L. Rob. \& Fernald) out-yielded others in year 3 when rainfall was the greatest. Herbage crude protein averaged approximately $100 \mathrm{~g} \cdot \mathrm{kg}^{-1}$ for bush-clovers (Lespedeza spp.) compared to bundle-flowers (Desmanthus spp.), which exceeded $200 \mathrm{~g} \cdot \mathrm{kg}^{-1}$; the latter also was high in herbage phosphorus. Herbage neutral detergent fiber ranged from 300 to more than $500 \mathrm{~g} \cdot \mathrm{kg}^{-1}$, acid detergent fiber ranged from 140 to $360 \mathrm{~g} \cdot \mathrm{kg}^{-1}$, and acid detergent lignin ranged from 36 to $140 \mathrm{~g} \cdot \mathrm{kg}^{-1}$, a wide range from which to select if animal nutrition is a primary criterion. Seed production was evaluated within a subset of 8 entries submitted to periodic herbage removal or left intact throughout the season. Three bundle-flowers yielded the greatest mass and seed number, but were negatively affected by harvest, unlike prairie acacia. Herbage and seed characteristics indicate there are promising perennial herbaceous legumes in the southern Great Plains that can be included in native seed mixes.
\end{abstract}

\section{Resumen}

Las mezclas de semillas nativas para la siembra de pastizales, restauración de praderas o pasturas cultivadas pueden beneficiarse de una gran variedad de hierbas que reflejan más cercanamente la vegetación original de las Grandes Planicies del sur. En la parte central de Texas se colectaron 15 leguminosas herbáceas perennes nativas y se evaluaron en dos años para ver su producción de forraje, contenido mineral y concentraciones de fibra de plantas establecidas en parcelas experimentales. "Downy milk-pea" (Galactia volubilis [L.] Britton) fue productiva sin importar la precipitación, mientras que "Prairie acacia" (Acacia angustissima [Mill.] Kuntze var. hirta [Nutt.] B.L. Rob.) e "Illinois bundle-flower" (Desmanthus illinoensis [Michx.] MacMill. Ex. B.L. Rob. \& Fernald) sobrepasaron en rendimiento a las otras especies en el tercer año, cuando se presentó la mayor precipitación. La proteína cruda del forraje promedió aproximadamente $100 \mathrm{~g} \cdot \mathrm{kg}^{-1}$ en el "Bush-clovers" (Lespedeza spp.) en comparación con el "Bundle-flowers" (Desmanthus spp.) que excedió los $200 \mathrm{~g} \cdot \mathrm{kg}^{-1}$, esta última también fue alta en fósforo. La fibra neutro detergente del forraje varió de 300 a más de $500 \mathrm{~g} \cdot \mathrm{kg}^{-1}$, la fibra ácido detergente de 140 a $360 \mathrm{~g} \cdot \mathrm{kg}^{-1}$, y la lignina ácido detergente de 36 a $140 \mathrm{~g} \cdot \mathrm{kg}^{-1}$, un rango amplio del cual seleccionar si la nutrición del animal es el principal criterio. La producción de semilla fue evaluada dentro de un subgrupo de 8 entradas sujetas a remoción periódica del forraje o con la hoja intacta a lo largo de la estación. Tres "Bundle-flowers" rindieron la mayor masa y número de semillas, pero fueron negativamente afectadas por la cosecha de forraje, menos la "Prairie acacia." Las características del forraje y la semilla indican que hay leguminosas herbáceas perennes prometedoras en las Grandes Planicies de sur que pueden ser incluidas en las mezclas de semillas nativas.

Key Words: herbage nutritive value, yield, wildlife, revegetation, rangeland

\section{INTRODUCTION}

Interest in the development and use of native herbaceous germplasm is increasing as plant scientists become more wary of introducing potentially weedy exotics. Legume species in particular are being sought for cultivated pasture (Springer

Research was funded in part by Texas Higher Education Coordinating Board grant 517-245-2001.

Correspondence: James Muir, Texas Agricultural Experiment Station, 1229 North US Highway 281, Stephenville, TX 76401. Email: j-muir@tamu.edu

Manuscript received 18 March 2004; manuscript accepted 8 August 2005. et al. 2001), roadside stabilization (Harper-Lore and Wilson 2000), wildlife plantings (Gee et al. 1994; Madison and Robel 2001), prairie and woodland restoration (Jackson 1999), and ornamental horticulture (Davis et al. 1994). Although seed companies have native seed mixes for these uses, these consist primarily of grass and only a few broadleaf species. A case in point is the paucity of commercially available native herbaceous legumes in the southeastern United States, where only Desmanthus illinoensis (Michx.) MacMill. Ex B.L. Rob. \& Fernald, Chamaecrista fasciculata (Michx.) Green, and more recently, Desmanthus bicornutus (S. Watson) (Ocumpaugh et al. 2004) are presently used in commercial conservation resource plantings, wildlife food plot mixes, or rangeland 
Table 1. Native, perennial herbaceous legumes evaluated for nutritive value in small plots near Stephenville, Texas.

\begin{tabular}{|c|c|c|}
\hline Latin binomial & Common name $^{1}$ & County collected \\
\hline $\begin{array}{l}\text { Acacia angustissima var. } \text { hirta }^{2} \\
\text { (Mill.) Kuntze (Nutt.) Rob. }\end{array}$ & Eastern prairie acacia & $\begin{array}{c}\text { Erath and } \\
\text { Brown }\end{array}$ \\
\hline Desmanthus acuminatus Benth & $\begin{array}{l}\text { Sharp-pod } \\
\text { bundle-flower }\end{array}$ & Erath \\
\hline $\begin{array}{l}\text { Desmanthus illinoensis }{ }^{2} \text { (Michx.) } \\
\text { MacMill. Ex B.L. Rob. \& Fernald }\end{array}$ & Illinois bundle-flower & Erath \\
\hline Desmanthus leptolobus ${ }^{2}$ Torr. \& Gray & Prairie bundle-flower & Erath \\
\hline Desmanthus velutinus ${ }^{2}$ Scheele & Velvet bundle-flower & $\begin{array}{c}\text { Erath and } \\
\text { Brown }\end{array}$ \\
\hline Desmodium paniculatum (L.) D.C. & Panicled tick-clover & Erath \\
\hline Desmodium tweedyi Britton & Tweedy's tick-clover & Erath \\
\hline Galactia volubilis (L.) Britton & Downy milk-pea & Erath \\
\hline $\begin{array}{l}\text { Indigofera miniata var. leptosephala } \\
\text { (Nutt. ex Torr. \& A. Gray) } \\
\text { B.L. Turner }\end{array}$ & Western scarlet pea & Erath \\
\hline Lespedeza procumbens ${ }^{2}$ Michx. & Creeping bush-clover & Erath \\
\hline Lespedeza stuever ${ }^{2}$ Nutt. & Tall bush-clover & Erath \\
\hline Neptunia Iutea (Leavenw.) Benth. & Yellow-puff neptunia & Erath \\
\hline $\begin{array}{l}\text { Neptunia pubescens var. microcarpa } \\
\text { Benth. (Rose) Windler }\end{array}$ & Tropical neptunia & $\begin{array}{l}\text { San Patrício and } \\
\text { Brazos }\end{array}$ \\
\hline $\begin{array}{l}\text { Rhynchosia senna var. texana } \\
\text { Gillies ex Hook. } \\
\text { (Torr. \& A. Gray) M.C. Johnst. }\end{array}$ & Texas snout-bean & Erath \\
\hline $\begin{array}{l}\text { Rhynchosia americana² } \\
\text { (Houst. ex Mill.) Metz }\end{array}$ & American snout-bean & San Patricio \\
\hline
\end{tabular}

${ }^{1}$ Common names according to Diggs et al. (1999)

${ }^{2}$ Entries included in seed data analyses.

seeding. None of these are as yet widely recommended in cultivated pasture seed mixes due to lack of seedling vigor, low productivity and persistence, and antiquality factors (Posler et al. 1993; Berg 1996; Jackson 1999; Nguluve et al. 2004).

In order to redress the herbaceous, perennial legume aspect of this situation, a native germplasm project was initiated at Stephenville, Texas. Species present in both grazed and protected native grasslands or woodlands, which appeared vigorous and produced abundant seed, were collected in central Texas. Very little is known about the majority of these species, especially under cultivated conditions. Although it has been surmised that herbaceous legumes adapted to the hot, dry summers and cold winters of the southern Great Plains were common before the advent of barbed wire (Weaver 1954; Lewis et al. 1974), these species have largely succumbed to overgrazing and monoculture of exotics. Diggs et al. (1999) identified more than 20 genera containing numerous perennial herbaceous legume species found in north-central Texas, but few of these have been considered for cultivation.

The trial reported in this article represents a first step in expanding knowledge of this group. The objective was to examine the herbage production, mineral concentration and fiber component characteristics that indicate potential nutritive value of native, perennial, herbaceous legumes collected primarily, but not exclusively, in the Cross Timbers region of north Texas. A secondary objective was to determine how recurrent herbage removal during the growing season affected seed production in a subset of these species. Data were collected under monoculture with no weed competition in order to determine whether further research in natural field conditions is merited for each entry.

\section{METHODS AND MATERIALS}

Seeds of 15 native perennial herbaceous legumes were collected from rangeland, pasture, and protected prairie or woodland sites in Texas (Table 1). Each species was collected in 4-12 distinct locations, and seeds were batched before mechanical scarification and inoculation with a general cowpea inoculant (Urbana Laboratories, St. Joseph, MO). In March 2000 and 2001, 2-3 seeds were placed in 300-mL containers of locally collected soil (upper $15 \mathrm{~cm}$ of a Windthorst fine sandy loam [fine, mixed, thermic Udic Paleustalf]). Seedlings were thinned to 1 per container, and these were watered and protected from frost in a greenhouse up to the 5-leaf stage before transplanting into research plots.

In 2000 and again in 2001, seedlings were transplanted using 50 -cm spacing into 8-plant, $2 \times 4 \mathrm{~m}$ plots at Stephenville, Texas (lat $32^{\circ} 13^{\prime} \mathrm{N}$, long $98^{\circ} 12^{\prime} \mathrm{W}, 399 \mathrm{~m}$ elevation in the Cross Timbers physiographic region of north-central Texas). The 2001 seedlings were to replace plants that did not survive the winter. This region is characterized by shallow, sandy, low-phosphorus soils with low water-holding capacity. Soil samples taken from the upper $15 \mathrm{~cm}$ of the experimental site had a pH of 6.8 and a soil analysis (plant-available nutrients in a slightly acidic extraction) (Hons et al. 1990; Texas A\&M Labs, College Station, TX) of $5 \mathrm{mg}$ phosphorus; $176 \mathrm{mg}$ potassium; $1777 \mathrm{mg}$ calcium, and $336 \mathrm{mg}$ magnesium per $\mathrm{kg}^{-1}$ of soil. No fertilizers were applied throughout the trial in an effort to emulate local soil conditions. No cultivation took place, and plant competition was reduced by spraying with clethodim ([E)-2-[1[(3chloro-2-propenyl)oxy]imino]propyl]-5-[2-(ethylthio)propyl]-3-hydroxy-2-cyclohexen-1-one) at $74 \mathrm{~g}$ active ingredient $\mathrm{ha}^{-1}$ and ammonium salt of imazethapyr (2-[4,5-dihydro-4-methyl-4-(1-methylethyl)-5-oxo-1H-imidazol-2-yl]-5-ethyl-3-pyridinecarboxylic acid) at $148 \mathrm{~g}$ active ingredient $\mathrm{ha}^{-1}$ in April of both the establishment and data collection years.

Seedlings were watered with $40 \mathrm{~mm}$ of water within 24 hours of transplanting. An additional $40 \mathrm{~mm}$ of irrigation were applied in July 2000, as well as in July, August, and September 2001 , when biweekly rainfall was less than $50 \%$ of the 30 -year average during those dry years. April to October rainfall amounted to 414, 319, and $630 \mathrm{~mm}$ for 2000, 2001, and 2002, respectively, with the 30 -year rainfall average being $540 \mathrm{~mm}$ (Fig. 1). Clipping of individual plants $(n=4$ per subplot) was initiated during 2001 following a 1-year establishment period and for 2002 when either canopies began to overlap or when flowering was initiated. Clipping was repeated every 30 days until growth stopped in the autumn. Plants were harvested individually by clipping leaves and branches to a maximum $15 \mathrm{~cm}$ stubble height (or branch length for prostrate plants) in an effort to measure only herbage that herbivores would normally remove (Lippke 2002). After drying herbage in a forced-air oven for 48 hours, sample weights for each cut were recorded and then totaled by season to give season-long herbage yields. 
Ripened seed was collected from both harvested and unharvested $(n=4)$ subplots whenever these matured to determine both yield and number per plant. Due to uneven plant survival in subplots, herbage yield and seed yield and number data were reported on a per plant basis in subplots pooled within year.

Representative subsamples of subplot herbage from each harvest were ground in a shear mill (Thomas-Wiley Co, Philadelphia, PA) through a 1-mm screen and batched by year. These were used to determine neutral detergent fiber (NDF), acid detergent fiber (ADF), and acid detergent lignin (ADL) concentrations in the plant tissue using the procedures described by Van Soest and Robertson (1980). To determine nitrogen and phosphorus in the herbage, samples were digested using a modification of the aluminum block digestion procedure described by Gallaher et al. (1975). Phosphorus and nitrogen in the digestate were determined by semiautomated colorimetry (Hambleton 1977) using a Technicon Autoanalyzer II (Technicon Industrial Systems, Tarryton, NY) and crude protein $(\mathrm{CP})$ was calculated by multiplying nitrogen concentrations by 6.25 .

The plots were arranged in a completely randomized design with 3 replications. For the herbage data, 15 entries were studied and data were collected during 2001 and 2002. Seed data were analyzed from only 8 entries because some entries did not produce seed both years (Table 1). Except for seed yield and number, in which herbage removal was used as an additional factor, analysis of variance was conducted using entries and years as factors and testing for interaction between these. A probability of 0.05 was used unless otherwise specified. Dependent variables included seed yield; herbage yield; and herbage NDF, ADF, ADL, phosphorus, and CP concentrations. Means, where there were significant differences, were separated using Fisher's Protected LSD test.

\section{RESULTS AND DISCUSSION}

\section{Herbage Yield}

A combination of more mature plants and greater soil water resulted in greater herbage production for 6 of the entries (Acacia angustissima var. hirta [prairie acacia], Lespedeza procumbens [creeping bush-clover], Rhynchosia americana [American snout-bean], Indigofera miniata var. leptosephala [Western scarlet pea], D. illinoensis [Illinois bundle-flower], and Desmanthus leptolobus [prairie bundle-flower]) the second year (2002) of the study compared to the first year (year $\times$ species interaction $P<0.01$; Fig. 2). These entries more than doubled their herbage yields the second year, indicating either a greater adaptation to improved moisture conditions or greater biomass as a result of an additional year's growth following establishment. As perennials, root expansion and crown/stem development likely increased each year after establishment. Prairie acacia and Illinois bundle-flower were particularly productive and appear to be promising candidates for cultivation in greater moisture systems. In the case of the bundle-flower, data collected by Piper (1998), who measured up to $6000 \mathrm{~kg} \cdot \mathrm{ha}^{-1} \cdot \mathrm{yr}^{-1}$ when rainfall reached nearly 1500 $\mathrm{mm}$, supports the conclusion that this species responds to rainfall beyond what was experienced in the present trial.

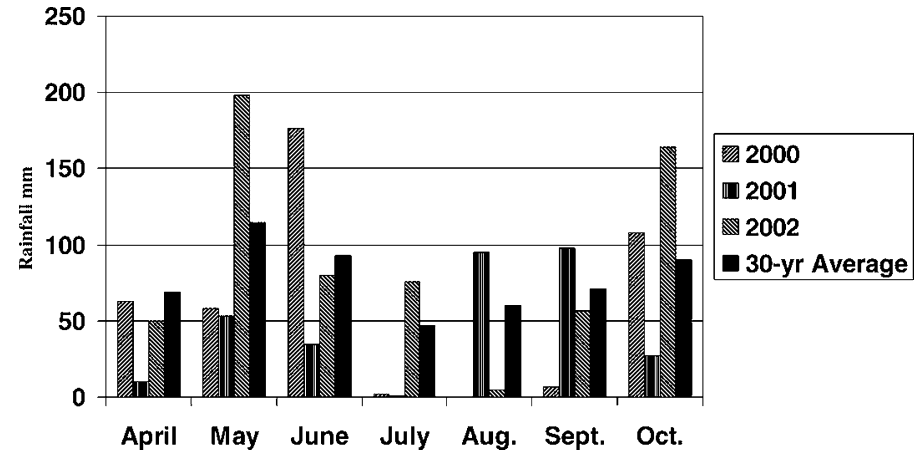

Figure 1. Monthly growing season rainfall for the study and 30-year averages at Stephenville, Texas.

In the drier, first year of data collection, Galactia volubilis (downy milk-pea) yielded nearly twice the herbage of any other entry. This, combined with the lack of measurable increase in yield the wet second year, indicates that the milk-pea, as well as Neptunia pubescens var. microcarpa (tropical neptunia), Desmanthus velutinus (velvet bundle-flower), and Desmanthus acuminatus (sharp-pod bundle-flower) are productive in dry conditions but did not respond to greater precipitation.

Some species were not productive either year, indicating slow growth in general or possibly a lack of adaptation to full sunlight or infertile soil conditions. In the Cross Timbers region, Desmodium paniculatum (panicled tick-clover), Desmodium tweedyi (Tweedy's tick-clover), downy milk-pea, and Rhynchosia senna var. texana (Texas snout-bean), are found primarily in shaded environments and a lack of adaptation to full sunlight may have contributed to low productivity in the full sunlight conditions of the study. Previous studies of perennial herbaceous North American legumes have indicated that some are more productive under partial shade (Muir and Pitman 1989b), and further study of Texas legumes are needed to indicate which are best adapted to growth under tree canopies. Fertility trials (especially phosphorus) may be required to determine how these species respond to soil amendments in low-phosphorus soils. Herbage growth for some native herbaceous legumes responded positively in greenhouse trials to increased plant-available soil phosphorus (Muir and Pitman 1989a; Osman et al. 2002).

\section{Herbage CP, Phosphorus, and Fiber Fractions}

Herbage CP concentration was unaffected by year. However, there were large differences among the entries. The species with the greatest concentration, prairie acacia, had $>90 \%$ greater $\mathrm{CP}$ than the 2 tick-clovers at the opposite end of the spectrum (Fig. 3). Most entries had close to or greater than $150 \mathrm{~g} \mathrm{CP} \mathrm{kg}^{-1}$, likely a desirable contribution to herbivore nutrition in either pasture or rangeland situations and comparable to other warm season legumes (Muir 2002; Nguluve et al. 2004). An increase in dietary legume CP levels ingested by ruminants has been correlated to increased digestibility of accompanying herbage, an especially important factor in diets dominated by low CP grasses (Said and Tolera 1993) typical of rangeland conditions during the warm season in this region. The inclusion of legume $\mathrm{CP}$ in ruminant diets can increase protein utilization efficiency because it can bypass rumen degradation (Broderick 1995). 


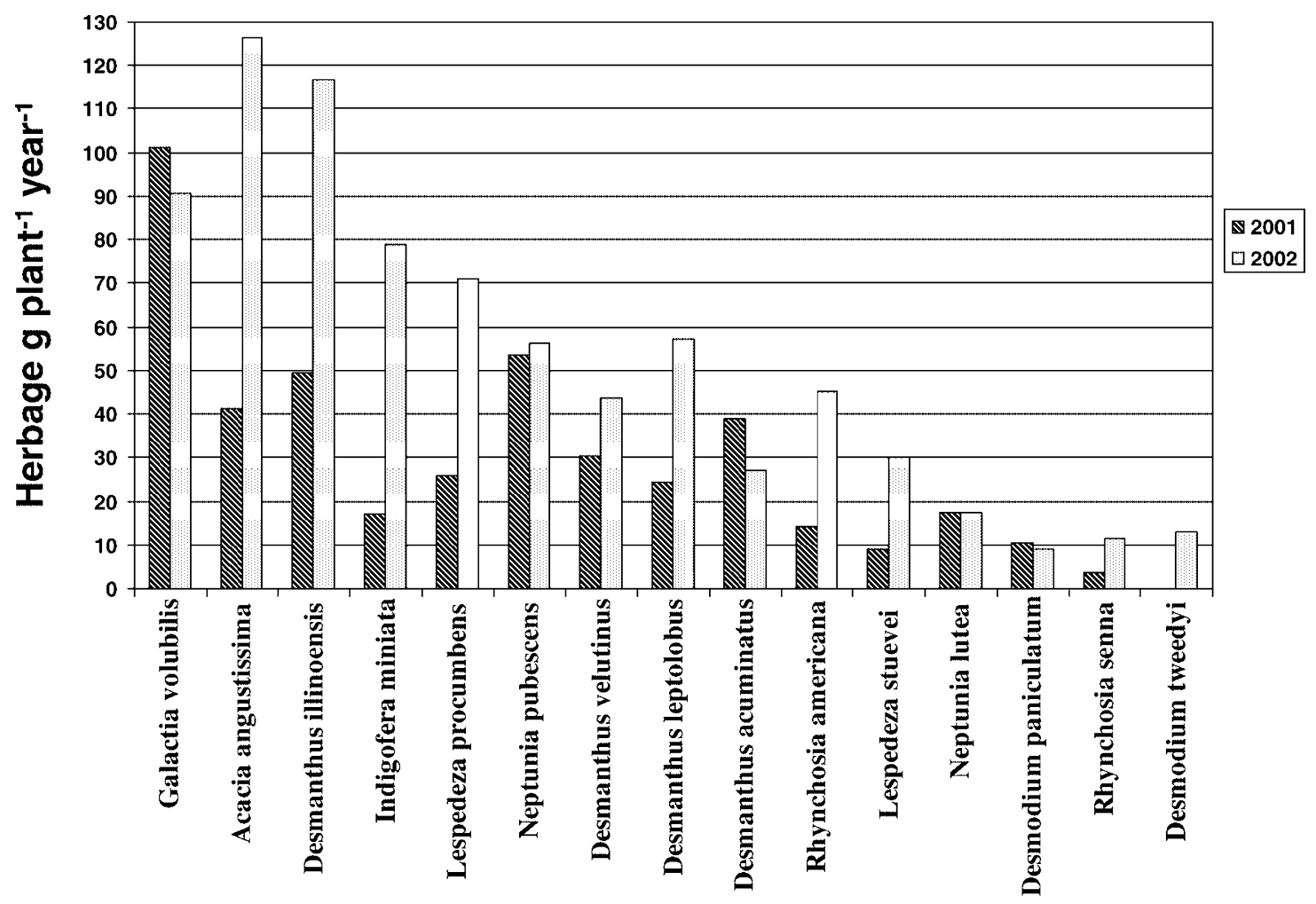

Figure 2. Herbage production of 15 native Texas perennial herbaceous legumes grown in plots over 2 years (year by species interaction $P<0.01$; $\left.2001 \mathrm{LSD}_{0.05}=28 ; 2002 \mathrm{LSD}_{0.05}=47\right)$.

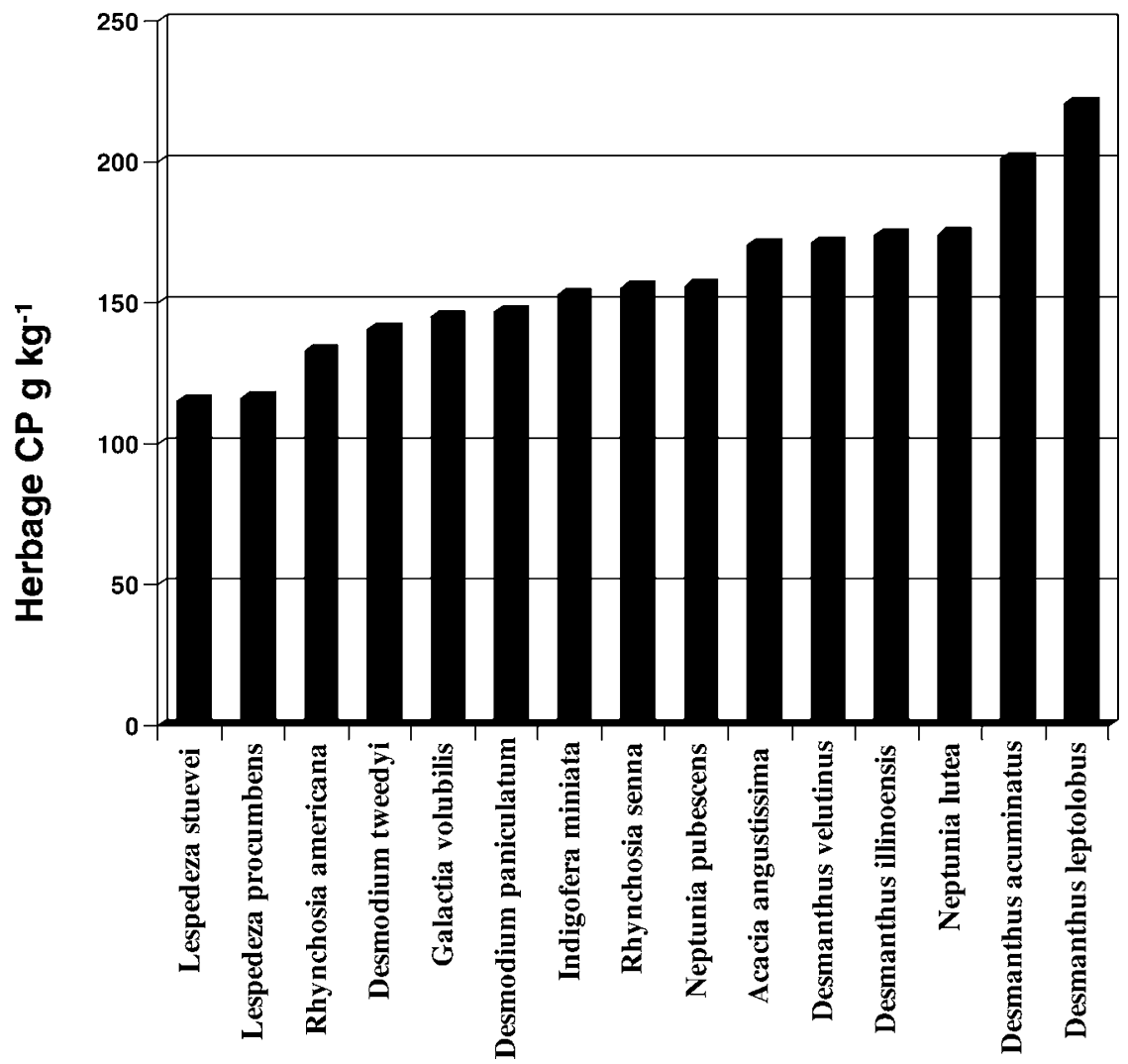

Figure 3. Herbage crude protein (CP) concentration of 15 native Texas perennial herbaceous legumes grown in plots (pooled over 2 years; $\left.P=0.001 ; \mathrm{LSD}_{0.05}=28\right)$. 


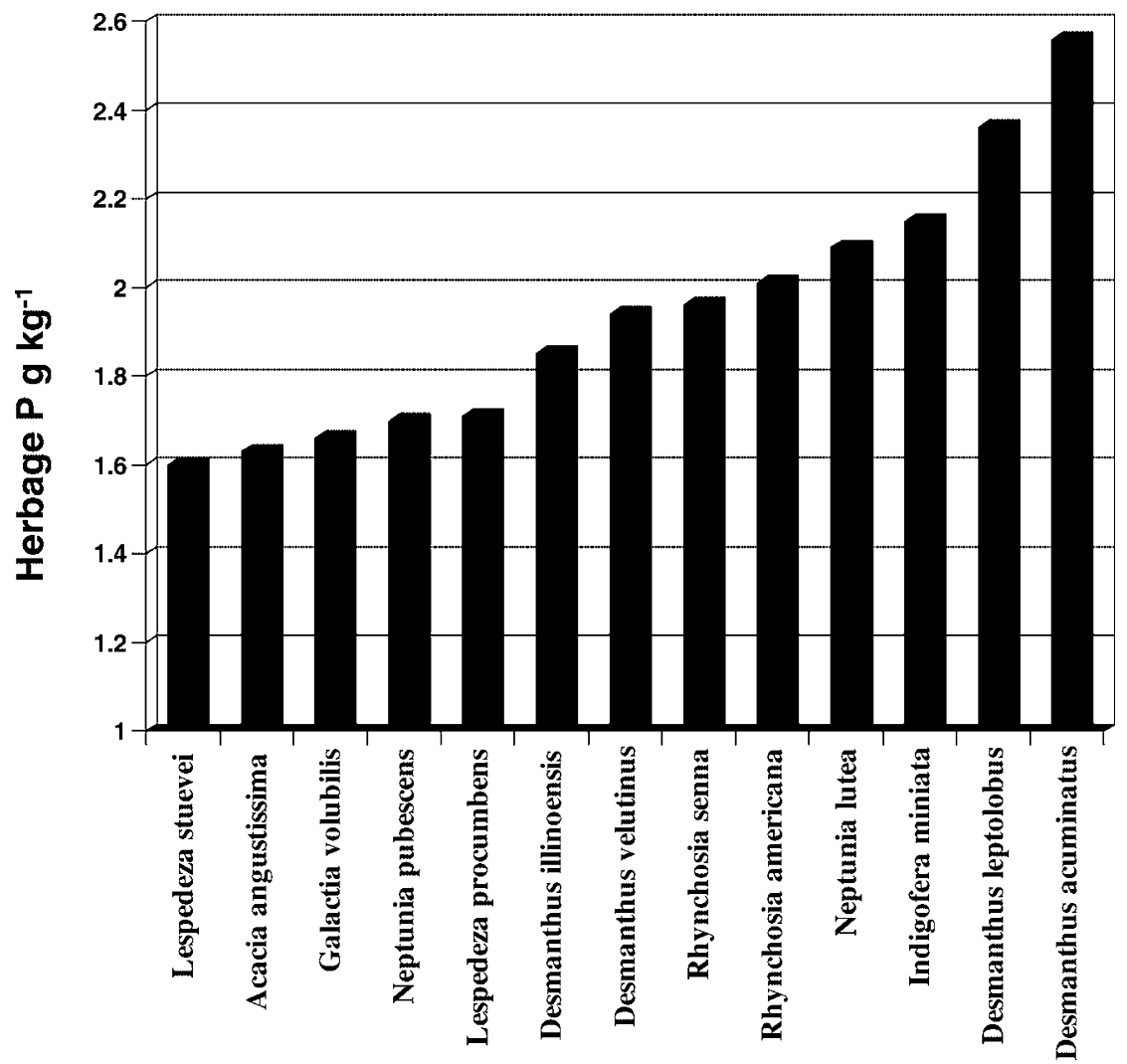

Figure 4. Herbage phosphorus concentration for 13 native, perennial herbaceous legumes in north-central Texas (pooled over 2 years; $P=0.001$; $\left.\mathrm{LSD}_{0.05}=0.31\right)$.

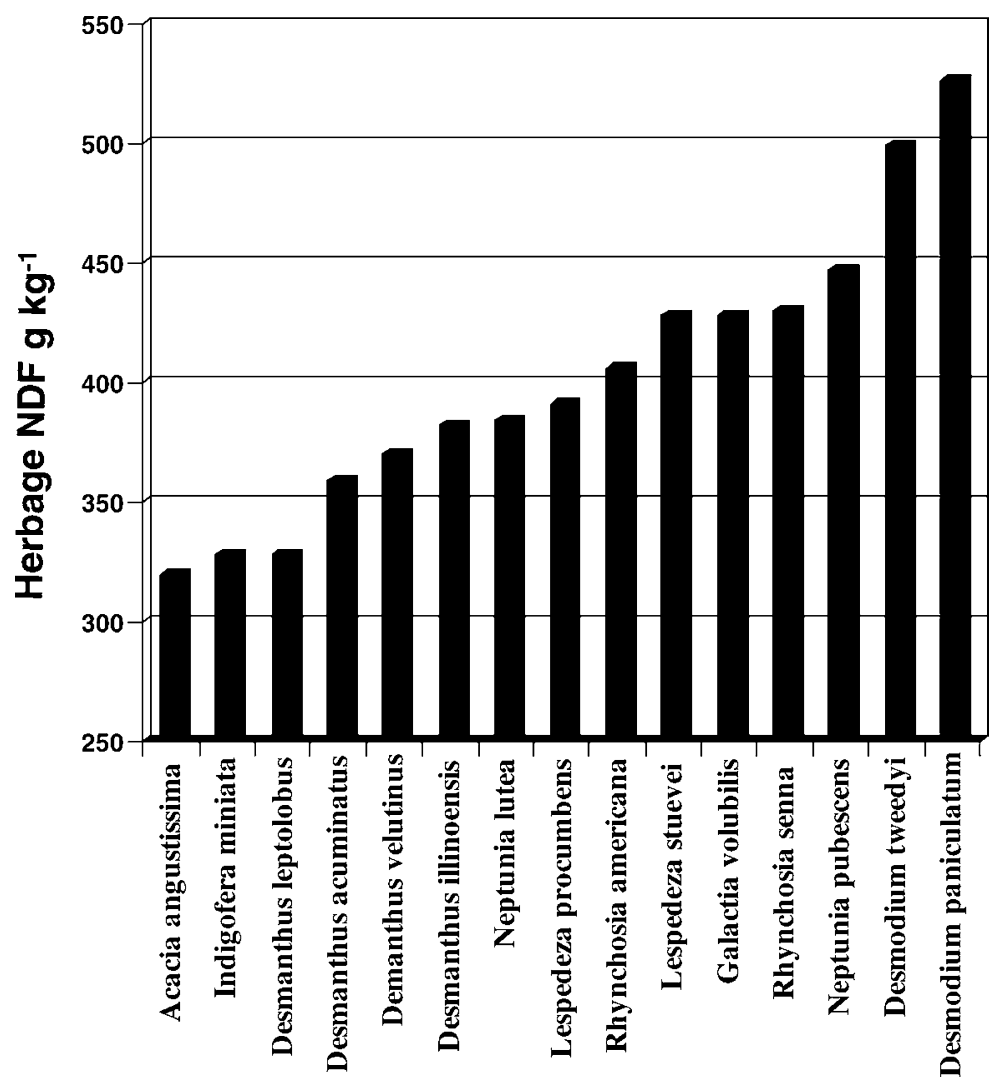

Figure 5. Herbage neutral detergent fiber (NDF) concentration for 15 native Texas perennial herbaceous legumes grown in plots (pooled over 2 years; $P<0.01 ; \mathrm{LSD}_{0.05}=44$ ). 


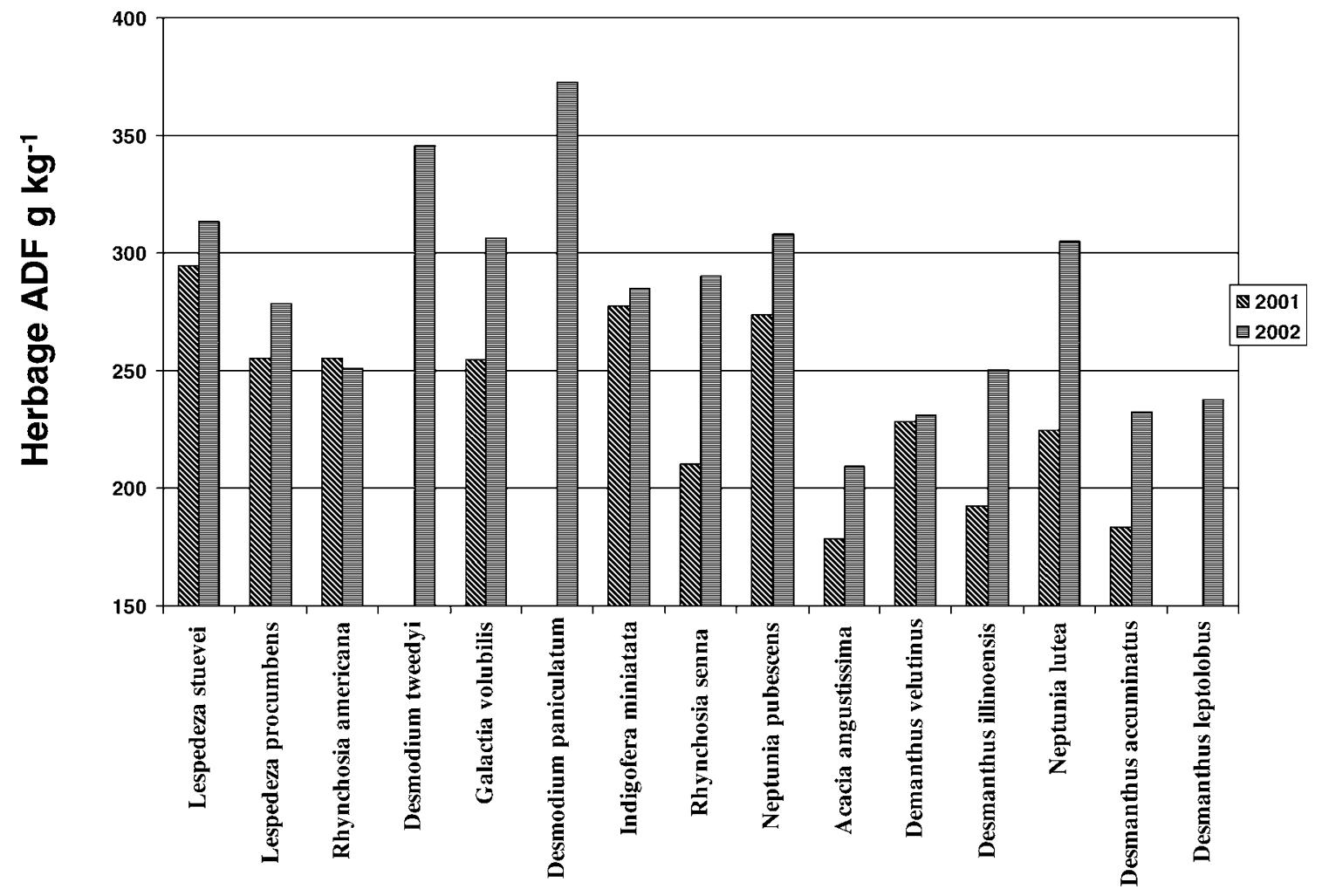

Figure 6. Herbage acid detergent fiber (ADF) concentration for 15 native Texas perennial herbaceous legumes grown in plots over 2 years (year by species interaction $P=0.02 ; \mathrm{LSD}_{0.05}=46$; missing data points for 2001 Desmodium spp. and Desmanthus leptolobus are due to insufficient herbage).

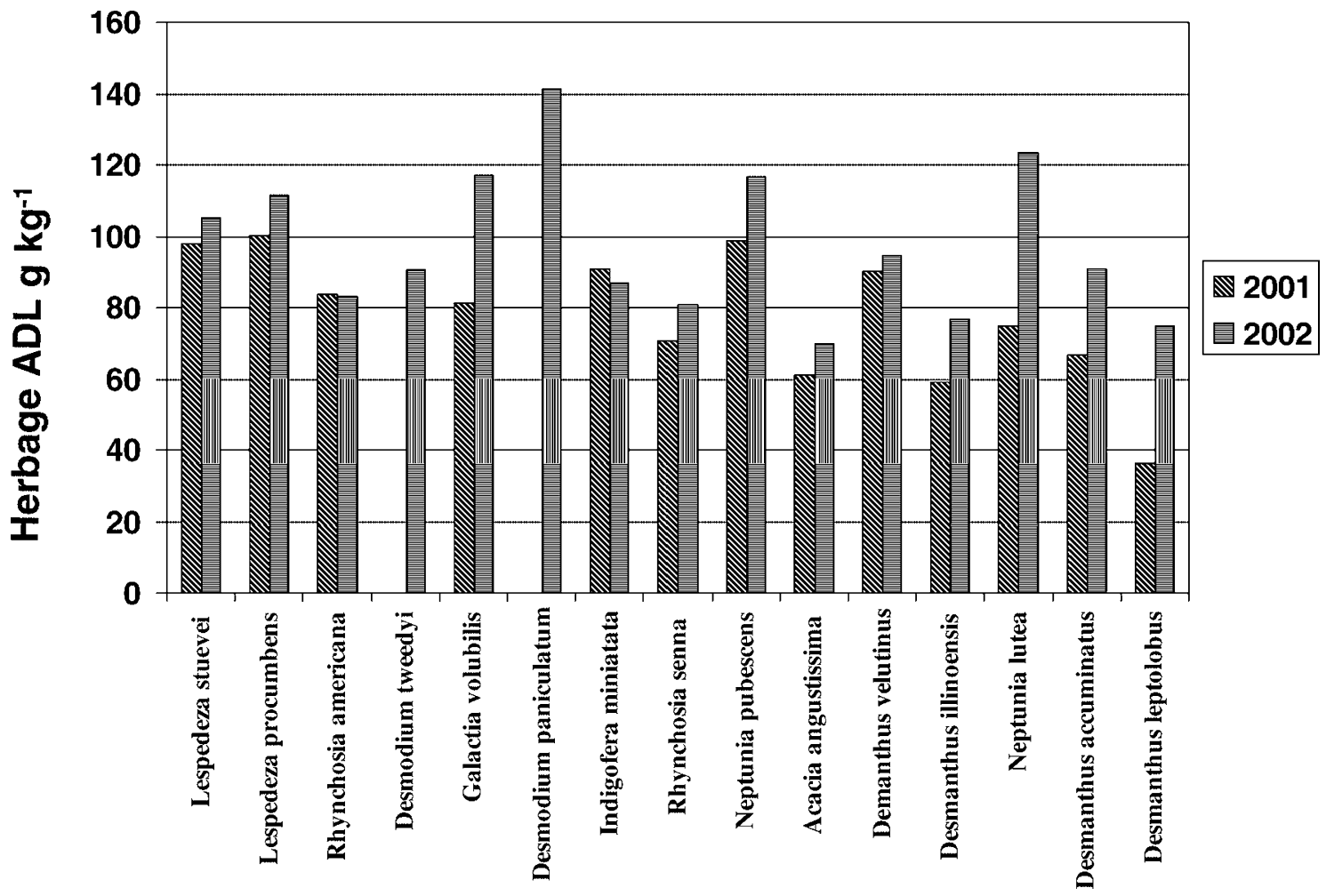

Figure 7. Concentration of herbage acid detergent lignin (ADL) for 15 native Texas perennial herbaceous legumes grown in plots over 2 years (year by species interaction $P=0.02 ; \mathrm{LSD}_{0.05}=19$; missing data points for 2001 Desmodium spp. and Desmanthus leptolobus are due to insufficient herbage). 
Herbage phosphorus concentration was likewise similar between years. Five of the entries had phosphorus concentrations greater than $2.0 \mathrm{~g} \cdot \mathrm{kg}^{-1}$ (Fig. 4) despite growing in soils with low levels of plant-available soil phosphorus relative to what is considered ideal for warm-season legume development (Maasdorp and Gutteridge 1986). Herbage phosphorus concentration in these 5 entries compares favorably with other warm-season perennial legumes grown in soils with greater levels of plant-available phosphorus (Pierzynski and Logan 1993; Nguluve et al. 2004).

Herbage NDF concentrations appear to group according to genera, regardless of year (Fig. 5). The 2 tick-clovers contained the greatest NDF concentrations, near $500 \mathrm{~g} \cdot \mathrm{kg}^{-1}$. As a group, the bundle-flowers had the lowest levels of NDF. The exception was Neptunia spp., with tropical neptunia having a greater NDF concentration than Neptunia lutea (yellow-puff neptunia). Prairie acacia, scarlet-pea, and prairie bundle-flower were particularly low in NDF, a fiber fraction that has been negatively correlated to herbage intake in ruminants (van Soest 1965; Oba and Allen 1999). Berg's (1996) report that steers actively selected Illinois bundle-flower and scarlet-pea in preference to other forbs in the southern Great Plains supports this conclusion because these 2 species were among the lowest in NDF concentration. Herbage nutritive value is an important consideration for the future use of these native legumes and for selection among low-NDF entries.

Herbage ADF concentrations were generally greater in 2002, the third growing season following establishment, than the second growing season (Fig. 6). This is a reflection of increased plant development in 2002 (Fig. 2) resulting in a greater proportion of stem materials in the samples. ADF can provide an estimate of digestibility (Minson 1982). The lower the fraction, the more digestible and the faster the passage rates. Herbage ADF concentrations were between 200 and $300 \mathrm{~g} \cdot \mathrm{kg}^{-1}$ with the exception of the 2 tick-clovers, and are comparable to other hand-plucked or clipped tropical or warm-season legumes (Muir 2002; Nguluve et al. 2004). Field observation of white-tailed deer and cattle utilizing tick-clovers in shaded lowlands indicates acceptability may not be as poor as ADF values would predict.

ADL is considered essentially indigestible, even in ruminants, and is therefore an indicator of passage rate (Weiss 1994). Data from this study support an initial conclusion that a wide range in digestibility exists among the species in this trial (Fig. 7). Prairie and Illinois bundle-flower and prairie acacia contained lower ADL concentrations, especially in the first year of herbage collection, than other entries. ADL in some entries was consistently greater than those reported in the literature for hand-plucked herbage of cultivated warm-season perennial or annual legumes (Muir 2002; Nguluve et al. 2004).

\section{Seed Yield and Number}

Herbage removal affected seed yield for 5 of the 8 species included in this aspect of the trial in both years (entry $\times$ harvest interaction $P=0.003$ ) (Fig. 8). The bundle-flowers, as a group, produced 2 to 4 times greater seed mass on plants that were not harvested compared to other entries. In a study with a shorter growing season but greater precipitation, Piper (1998) measured the equivalent of $12-30 \mathrm{~g}$ seed plant ${ }^{-1} \cdot \mathrm{yr}^{-1}$ produced by unharvested cultivated Illinois bundle-flower. This value is within the range of the seed yields measured for Illinois bundle-flower in this study. Little has been reported in the literature on the seed production for the other entries, whether growing in natural or cultivated conditions.

Seed yield data indicate that, even among closely related species of the bundle-flower trio, response to herbage removal stress differs. Illinois bundle-flower exhibited a far more precipitous drop $(90 \%)$ in seed yield in response to herbage removal than the prairie $(68 \%)$ or velvet $(45 \%)$ bundle-flowers. Compare this to the diametrically opposite response, $85 \%$ increase in seed yield, shown by prairie acacia when submitted to herbage removal. The dynamics of nutrient allocation and relative investment in reproductive activity (especially as it relates to prairie acacia's rhizomatous reproduction in addition to seed yields) merits further study and may, eventually, relate to commercial application of these species as either herbage, seed-producing, or dual-purpose plants.

The number of seeds produced per plant is related to seed yield but provides other information that directly relates to future studies in seedling recruitment and stand persistence. Seed number (Table 2) differed among species, depending on harvest treatment and year (year $\times$ harvest $\times$ species interaction $P=0.03$ ). Numbers increased considerably from the first harvest year in 2001 to 2002 for all species except prairie acacia and creeping bush clover. Two factors that positively affected seed set were greater rainfall or advancing plant maturity (or both). This trait merits further research, especially to determine whether plant maturity levels, shoot competition (visual indications are that more shoots volunteered in 2002), or decreased plant stress (greater precipitation) inhibit seed set in this species.

Herbage removal decreased seed numbers for some species. Herbage removal will decrease leaf area and subsequent stored carbohydrate (Muir and Pitman 1991), which is essential in reproductive efficiency. In this study, the exception was American snout-bean, which produced greater numbers of seed on harvested plants during the second year. The American snoutbean appears to respond to herbage removal in high precipitation years by setting greater numbers of seed, but further study is needed to verify this response and determine whether this is accomplished at the expense of stored carbohydrate.

A comparison of the seed numbers between unharvested plants of the 3 bundle-flowers (Table 2) showed a marked difference in response to improved growing conditions, possibly compounded by plant maturity, among species within this genus. From 2001 to 2002, Illinois bundle-flower had a 360\% increase in seed number, compared to a $220 \%$ increase for prairie bundleflower and a $105 \%$ increase for velvet bundle-flower. Greater herbage production, however, appears to translate into greater numbers of seed set at different rates for these species (Fig. 2). From 2001 to 2002, Illinois bundle-flower herbage increase/seed yield ratios were 1.44 compared to 0.96 for prairie bundleflower and 0.75 for velvet bundle-flower. Illinois bundle-flower utilized increased herbage growth to produce greater numbers of seed more effectively than the other 2 bundle-flowers.

\section{MANAGEMENT IMPLICATIONS}

Some of these species appear to reach peak growth within a year of transplanting and produce appreciable amounts of 


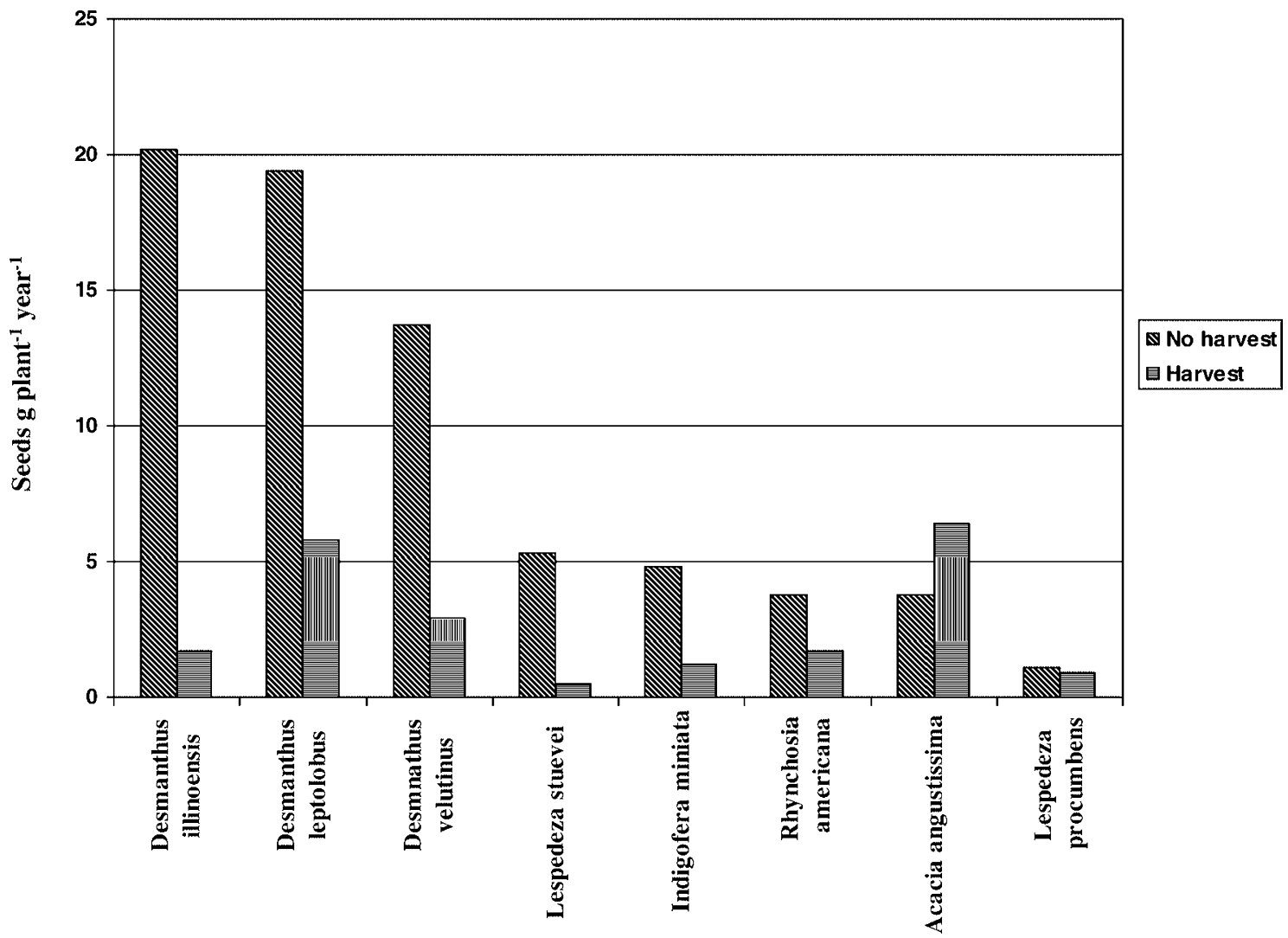

Figure 8. Seed mass produced by 8 native, herbaceous perennial legumes in north-central Texas after plants were harvested or not harvested during the growing season (batched over 2 years; entry by harvest interaction $P=0.003 ; \mathrm{LSD}_{0.05}=3.1$ ).

herbage even in low soil-moisture conditions. Downy milk-pea, for example, averaged the equivalent of $3800 \mathrm{~kg}$ herbage $\mathrm{ha}^{-1} \cdot \mathrm{yr}^{-1}$ (estimated on a $0.5 \mathrm{~m}$ between plant basis) in both the drier second year following establishment and the subsequent wetter year. In contrast, prairie acacia and Illinois bundle-flower yielded the equivalent of 1600-2 $000 \mathrm{~kg}$ herbage $\mathrm{ha}^{-1}$ the second, drier year following establishment but responded to greater precipitation the third year after estab-

Table 2. Number of seeds produced by 8 native perennial herbaceous legumes submitted to periodic harvest or unharvested, 2 and 3 years after establishment (year $\times$ harvest $\times$ species interaction $P=0.03$; $\mathrm{LSD}_{0.05}=710$ between columns within years).

\begin{tabular}{|c|c|c|c|c|}
\hline \multirow[b]{2}{*}{ Entry } & \multicolumn{2}{|c|}{2001} & \multicolumn{2}{|c|}{2002} \\
\hline & No harvest & Harvest & No harvest & Harvest \\
\hline & \multicolumn{4}{|c|}{----------------------- Seeds/plant----------------------- } \\
\hline Desmanthus illinoensis & $3365 a^{1}$ & $368 a b$ & $12136 \mathrm{a}$ & $545 \mathrm{a}$ \\
\hline Desmanthus leptolobus & $2346 b$ & $1004 \mathrm{a}$ & $5244 b$ & $1574 \mathrm{a}$ \\
\hline Desmanthus velutinus & 3231 a & $286 a b$ & 3384 bc & $1126 \mathrm{a}$ \\
\hline Rhynchosia americana & $149 \mathrm{c}$ & $41 \mathrm{~b}$ & 2034 bc & $2919 \mathrm{a}$ \\
\hline Lespedeza stuevei & $512 \mathrm{c}$ & $8 \mathrm{~b}$ & $4030 \mathrm{bc}$ & $488 \mathrm{a}$ \\
\hline Indigofera miniata & $550 \mathrm{c}$ & $123 \mathrm{ab}$ & 2078 bc & $1986 \mathrm{a}$ \\
\hline Acacia angustissima & $1045 c$ & $1035 \mathrm{a}$ & $88 \mathrm{c}$ & $57 \mathrm{a}$ \\
\hline Lespedeza procumbens & $818 \mathrm{c}$ & $566 \mathrm{ab}$ & $265 \mathrm{c}$ & $437 \mathrm{a}$ \\
\hline
\end{tabular}

${ }^{1}$ Means within the same column differ $(P=0.05)$ according to Fisher's Protected LSD; multiple-range separation if followed by different letters. lishment by producing the equivalent of nearly $4800 \mathrm{~kg}$ herbage $\mathrm{ha}^{-1} \cdot \mathrm{yr}^{-1}$. In rangeland situations, these legumes contribute only a fraction of this potential herbage because they will be only one component of a complex plant community, but their contribution is an important one.

Differences in herbage mineral and fiber composition indicate a wide range in herbage nutritive value among the species included in this study. End-users looking for native herbaceous legumes for cultivated pasture or rangeland seeding need to look for entries with high CP and low ADF or ADL concentrations. Downy milk-pea, for example, consistently produced high herbage yields, but nutritive values were lower than equally productive species such as Illinois bundle-flower or prairie acacia.

If seed production for game bird feed or ease of propagation is the primary goal, then herbage yield or nutritive value is less important than seed yield. Species in this study varied considerably in their response to improved growing conditions: some allocated a greater proportion of their resources to herbage production, whereas others favored seed production. If improved herbivore nutrition is the principal goal, herbage yield and, more importantly, nutritive value, need to be factored into selection criteria. If ground cover and stabilization are of primary interest, then plant development or reproduction (vegetative or seedling recruitment) need greater consideration. If seed production for wildlife feed or seedling recruitment on bare soils is the primary goal, then those entries that invested more heavily in seed production would be of greater interest. 


\section{LITERATURE CITED}

BERG, W. A. 1996. Native forb persistence under grazing of a southern Great Plains planting. In: Proceedings of the 5th International Rangeland Congress; 23-28 July 1995. Salt Lake City, UT: Society for Range Management. 346 p.

BRODERICK, G. A. 1995. Desirable characteristics of forage legumes for improving protein utilization in ruminants. Journal of Animal Science 73:2760-2773.

Davis, T. D., S. W. George, W. A. Mackay, and J. M. Parsons. 1994. Development of Texas bluebonnets into floricultural crops. HortScience 29:1110-1116.

Diggs JR, G. M., B. L. Lipscomb, and R. J. O'Kennon. 1999. Shinners \& Mahler's illustrated flora of north central Texas. Fort Worth, TX: Botanical Research Institute of Texas. $1626 \mathrm{p}$.

Gallaher, R. N., C. O. Weldon, and J. G. Futral. 1975. An aluminum block digester for plant and soil analysis. Soil Science Society America Proceedings 39:803-806.

Gee, K. L., M. D. Porter, S. Demarais, F. Bryant, and G. van Vreede. 1994. Whitetailed deer: Their foods and management in the Cross Timbers. 2nd ed. Ardmore, OK: Samuel Roberts Noble Foundation. 118 p.

Hambleton, L. G. 1977. Semiautomated method for simultaneous determination of phosphorus, calcium and crude protein in animal feeds. Journal of Association of Official Analytical Chemists 60:845-852.

Harper-Lore, B., and M. WiLSON. 2000. Roadside use of native plants. Covelo, CA: Island Press. $663 \mathrm{p}$.

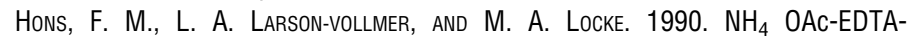
extractable phosphorus as a soil test procedure. Soil Science 149:249-256.

JACKSON, L. L. 1999. Establishing tallgrass prairie on grazed permanent pasture in the upper Midwest. Restoration Ecology 7:127-138.

Lewis, C. E., H. E. Grelen, L. D. White, and C. W. Carter. 1974. Range resources of the South. Bull. N. S. 9. Athens, GA: Georgia Agricultural Experiment Station. 9 p.

LIPPKE, H. 2002. Estimation of forage intake by ruminants on pasture. Crop Science 42:869-872.

MaAsdorp, B. V., and R. C. Gutteridge. 1986. Effect of fertilizer and weed control on the emergence and early growth of five leguminous fodder shrubs. Tropical Grasslands 20:127-134.

Madison, L. A., And R. J. Robel. 2001. Energy characteristics and consumption of several seeds recommended for northern bobwhite food plantings. Wildlife Society Bulletin 29:1219-1227.

Minson, D. J. 1982. Effect of chemical composition on feed digestibility and metabolizable energy. Nutrition Abstracts Review (B) 52:592-614.

MuiR, J. P. 2002. Hand-plucked forage yield and quality and seed production from annual and short-lived perennial warm-season legumes fertilized with composted manure. Crop Science 42:897-904.

Muir, J. P., And W. D. Pitman. 1989a. Response of Desmodium heterocarpon and Galactia elliottii to rhizobia and soil amendments. Journal of Plant Nutrition 12:1409-1416.
Muir, J. P., and W. D. Pitman. 1989b. Response of the Florida legume Galactia elliottii to shade. Agroforestry Systems 9:233-239.

MuiR, J. P., And W. D. Pitman. 1991. Responses of Desmanthus virgatus, Desmodium heterocarpon and Galactia elliottii to autumn clipping. Tropical Grasslands 25:291-296.

Nguluve, D., J. P. Muir, R. Wittie, R. Rossiere, and T. J. Butler. 2004. Yield and quality of summer legumes as influenced by dairy manure compost and crabgrass. Agronomy Journal 96:812-817.

OBA, M., AND M. S. Allen. 1999. Evaluation of the importance of the digestibility of neutral detergent fiber from forage: effects on dry matter intake and milk yield of dairy cows. Journal of Dairy Science 82:589-596.

Ocumpaugh, W. R., W. J. Grichar Jr, M. A. Hussey, A. H. Abrameit, M. K. Owens, R. L. Reed, J. P. Muir, D. Bade, And J. L. Relley. 2004. Registration of 'BeeTam-06' Bundleflower. Crop Science 44:1860-1861.

Osman, E. H., J. P. Muir, and A. Eglisman. 2002. Effect of Rhizobium inoculation and phosphorus application in native Texas legumes grown in local soil. Journal of Plant Nutrition 25:75-92.

Pierzynski, G. M., and T. J. Logan. 1993. Crop, soil, and management effects on phosphorus soil test levels. Journal of Production Agriculture 6: 513-520.

PIPER, J. K. 1998. Growth and seed yield of three perennial grains within monocultures and mixed stands. Agriculture, Ecosystems \& Environment 68:1-11.

Posler, G. L., A. W. Lenssen, And G. L. Fine. 1993. Forage yield, quality, compatibility, and persistence of warm-season grass-legume mixtures. Agronomy Journal 85:554-560.

Said, A. N., And A. Tolera. 1993. The supplementary value of forage legume hays in sheep feeding: feed intake, nitrogen retention and body weight change. Livestock Production Science 33:229-237.

Springer, T. L., G. E. Aiken, and R. W. McNew. 2001. Combining ability of binary mixtures of native, warm-season grasses and legumes. Crop Science 41: 818-823.

VAN SOEST, P. J. 1965. Symposium on factors influencing the voluntary intake of herbage by ruminants. Voluntary intake in relation to chemical composition and digestibility. Journal of Animal Science 24:834-843.

Van Soest, P. J., And J. B. Robertson. 1980. Systems of analysis for evaluating fibrous feeds. In: W. J. Pigden, C. C. Balch, and M. Graham (EDS.). Standardization of Analytical Methodology for Feeds: Proceedings of an International Workshop; 12-14 March 1979; Ottawa, ON. Report IDRC-134e. Ottawa, ON: International Development Research Centre and New York, NY: Unipub. 128 p.

Weaver, J. E. 1954. North American prairie. Lincoln, NE: Johnsen Publishing Co. $348 \mathrm{p}$.

WEISS, W. P. 1994. Estimation of digestibility of forages by laboratory methods. In: G. C. Fahey Jr. (ED.). Forage quality, evaluation, and utilization. Madison, WI: American Society of Agronomy. p. 644-681. 